\title{
JATI DIRI PEREMPUAN MENURUT KEJADIAN 1-2 DAN RELEVANSINYA BAGI SIKAP KRISTIANI TERHADAP PENGARUH GERAKAN FEMINISME DI INDONESIA
}

\author{
Maria Hanie Endojowatiningsih
}

\section{KATA PENGANTAR}

Di negara-negara berkembang, kaum perempuan mengalami nasib yang kurang menyenangkan, karena diposisikan sebagai kaum yang dianggap lebih lemah, lebih rendah, kurang berarti, orang belakang, tidak punya hak suara atau menyampaikan pendapat. Hal ini disebabkan karena faktor budaya paternalistik, atau sistem patriarkat dalam masyarakat Timur juga pada negeranegara berkembang lainnya. Secara jujur dapat dikatakan bahwa budaya ini terefleksi juga dalam gereja yang tentunya melandasi doktrin atau peraturan gerejanya dari teks-teks Alkitab, misalnya dari 1 Korintus 34-35, bahwa perempuan tidak boleh mengajar atau berbicara di depan umum. Juga karena perempuan dianggap penyebab kejatuhan Adam dalam dosa (Kej. 3), maka perempuan dinilai penyebab dosa, dan karena itu harus menerima kutuk "di bawah kekuasaan laki-laki/ suaminya").

Kaum perempuan yang menyadari keberadaannya sebagai ciptaan Tuhan yang sederajat dan memiliki hak-hak yang sama dengan laki-laki, maka mereka ingin membebaskan diri dari belenggu budaya patriarkhat dan melakukan gerakan yang terorganisir, yakni Gerakan Feminisme. Gerakan ini juga memengaruhi dunia Theologia, sehingga lahir Theologia Feminis, yang juga berdampak kepada penafsiran Alkitab, yang menguntungkan kaum perempuan.

Di satu sisi gerakan Feminisme bermuatan dan bertujuan sangat positif, namun seiring dengan bergulirnya waktu, maka gerakan ini menimbulkan ekses-ekses negatif, yang juga berdampak pada gereja atau orang Kristen. Karena itu penting orang Kristen memiliki sikap yang benar terhadap gerakan ini. Di satu sisi, gerakan ini mengingatkan orang Kristen tentang jati diri 
perempuan sebagai ciptaan yang sama mulia dengan laki-laki, karena diciptakan menurut gambar/rupa Allah sendiri. Karena itu orang Kristen bukan karena gerakan Feminisme, baru menempatkan perempuan secara proposional. Bahkan orang Kristen perlu menolak ekses-ekses negatif dari gerakan ini.

\section{PENDAhuluan}

Pada Pendahuluan ini, penulis akan menguraikan tentang latar belakang masalah, rumusan masalah, kegunaan penulisan, dan definisi istilah.

\section{A. LATAR BELAKANG MASALAH}

Secara theologis, perempuan dan laki-laki diciptakan Tuhan sederajat dengan mandat yang sama dengan laki-laki, meskipun fungsinya berbeda, sebagaimana ditulis dalam kitab Kejadian 1-2. Dengan demikian jelas bahwa bahwa tidak ada perbedaan derajat, tidak ada diskriminasi gender, karena keduanya diciptakan menurut gambar Allah, atau menurut citra Ilahi. Dan di dalam catatan sejarah, baik pada Perjanjian Lama maupun Perjanjian Baru, tidak jarang bahwa Tuhan pun memakai kaum perempuan untuk masuk dalam sejarah keselamatan, misalnya: Debora, Ruth, Rahab, Miryam, Maria, dsb. Namun tidak bisa dipungkiri, dalam realitas sosial-kultural-agama, antara keduanya seringkali terjadi diskriminasi, yang melahirkan tindak kekerasan, terutama kepada kaum perempuan. Dan diskriminasi tersebut telah merugikan perempuan atas kondisi dan posisinya, baik dalam kehidupan sosial, politik, ekonomi, dan budaya. Di masyarakat Indonesia sendiri, sering disaksikan tindak kekerasan terhadap perempuan dengan berbagai manifestasinya. Kekerasan fisik, kekerasan emosional, dan kekerasan psikhologi, baik secara domestik (dalam rumah) maupun publik (dilakukan oleh masyarakat: agama, media massa, kekuatan ekonomi, politik, dan negara), kerap menjadi tontonan gratis. ${ }^{1}$

Tindak diskriminatif terhadap kaum perempuan, secara teologis dihubungkan dengan peristiwa di Taman Eden, di mana dianggap Hawa-lah

\footnotetext{
1 Aloys Budi Purnomo, dalam artikel "Agama \& Kekerasan Terhadap Perempuan". http//www.kesrepo.info/?q=rode/186. Diakses tgl. 21-12-2009. h.1
} 
penyebab kejatuhan Adam, suaminya, dan dianggap penyebab dosa masuk menguasai seluruh umat manusia. Secara biologis dan psikhologis, laki-laki dianggap lebih kuat, lebih pemberani, lebih tegar, dan lebih cerdas khususnya dalam membuat berbagai perencanaan. Sedangkan perempuan dianggap lebih lembut, penakut, selalu memakai perasaannya. ${ }^{2}$

Pengalaman diskriminatif terhadap kaum perempuan juga terjadi di belahan dunia lainnya. Di Afrika di satu sisi menghormati perempuan sebagai penerus dan pemelihara kehidupan. Perempuan yang berusia lanjut diakui sebagai penasihat yang berwibawa karena dianggap berhikmat. Namun ada juga tradisi yang meremehkan kaum perempuan, seperti misalnya ada ritual yang menekan janda dan menyunat anak gadis. Penjajahan yang bersifat patriarkhat, rezim otoriter, dan kebijaksanaan ekomomi, melemahkan kedudukan perempuan. Di Amerika Latin, warisan kolonial masih berpengaruh kuat, misalnya perempuan harus patuh pada laki-laki. Perempuan miskin harus berjuang seorang diri demi keluarganya. Dan di Asia, perempuan pada umumnya dilihat sebagai pelengkap laki-laki, kurang berhak atas warisan dan kedudukannya sangat lemah. ${ }^{3}$

Dari pengalaman tersebut di atas, maka lahirlah gerakan Feminisme. Lahirnya gerakan Feminisme ini tidak bisa dilepaskan dari gerakan pembebasan kaum marginal, atau kaum tertindas, termasuk kaum perempuan, yang sudah dimulai di Eropa pada abad 19. Dan secara khusus di Amerika Latin, tantangan utama adalah soal pemilikan dan penggunaan tanah, yang terjadi kesenjangan tajam antara tuan tanah dengan para pekerjanya yang miskin. Juga diskriminasi berdasarkan ras. Maka dalam kesempatan inilah, kaum wanita pun membela hak-haknya, dan ingin membebaskan diri dari kungkungan patriarkat yang mendominasi di hampir semua suku dan bangsa. ${ }^{4}$

Bagaimana halnya dengan di Indonesia? Gerakan Feminisme juga telah merambah ke masyarakat Indonesia, yakni kesadaran akan citra dirinya yang sederajat dengan laki-laki. Sebagai contoh kesadaran ini adalah kerinduan dan perjuangan Raden Ajeng Kartini yang memperjuangkan agar kaum perempuan

${ }^{2}$ Ibid, h. 2

${ }^{3}$ Marie Claire Barth-Frommel, Hati Allah Bagaikan Hati Seorang Ibu. Pengantar Teologi Feminis. Jakarta: BPK Gunung Mulia, 2003, h. 18-19

${ }^{4}$ Ibid. : h. $14-15$ 
memperoleh hak dan kesempatan yang sama dengan kaum laki-laki, dalam hal perlakuan dan maupun kesempatan belajar, dan terlepas dari belenggu adat dan kepercayaan yang tidak menguntungkan bagi kaum perempuan. Di kalangan gereja pun diskriminasi terhadap kaum perempuan cukup terasa di beberapa denominasi gereja. Perempuan dianggap tidak mampu menjadi gambar Allah, sehingga dilarang menjadi pemimpin, pengkhotbah dan pengajar dalam ibadah maupun pelayanan gereja. ${ }^{5}$ Namun di beberapa denominasi gereja tertentu sudah memberi penghargaan kepada kaum perempuan, dan memberi tempat yang proporsional, baik dalam pelayanan maupun dalam keluarga dan dalam bermasyarakat.

Dengan latar belakang inilah, penulis tertarik untuk membahas tentang: Jati Diri Perempuan Menurut Kejadian 1-2 dan Relevansinya Bagi Sikap Etis Kristen terhadap Pengaruh Gerakan Feminisme di Indonesia.

\section{B. KEGUNAAN PENULISAN}

Dengan pembahasan makalah tentang Jati Diri Perempuan Menurut Kejadian 1-2 dan Relevansinya Bagi Sikap Etis Kristen terhadap Pengaruh Gerakan Feminisme di Indonesia, maka akan:

1. Menolong orang Kristen memahami dengan sungguh-sungguh jati diri manusia menurut Firman Tuhan, khususnya dalam kitab Kejadian 1-2 sehingga bisa menempatkan perempuan pada posisi yang tepat serta memberi penghargaan yang sewajarnya.

2. Menyadarkan orang Kristen bahwa Gerakan Feminisme bukanlah jawaban atas 'nasib' kaum perempuan di hadapan para laki-laki.

3. Memberi pembekalan orang Kristen bagaimana sikap yang tepat terhadap Gerakan Feminisme.

\section{DEFINISI ISTILAH}

${ }^{5}$ Lie Ing Sian, Sebuah Tinjauan terhadap Teologi Feminis Kristen. www.seabs.ac.id. Diakses 29-12-2009, h.3 
Dalam pokok bahasan makalah ini ada beberapa istilah yang perlu dijelaskan secara khusus, yaitu:

1. Kata jati diri terdiri dari dua kata yaitu jati dan diri. Kata jati berarti "sebenarnya, tulen, asli, murni, tidak ada campurannya", sedangkan kata diri berarti "ciri-ciri gambaran atau keadaan khusus seseorang atau suatu benda; identitas, jiwa semangat, dan daya gerak dari dalam; spiritualitas". 6

2. Relevansi adalah "perlunya hubungan pertalian atau sangkut pautnya dengan sesuatu hal."”

3. Sikap Kristiani adalah sikap orang Kristen sesuai standar Alkitab.

4. Gerakan Feminisme adalah gerakan terorganisir yang memperjuangkan pembebasan kaum perempuan untuk mendapatkan hak asasi perempuan.

\section{JATI DIRI PEREMPUAN MENURUT KEJADIAN 1-2}

Nama Kitab Kejadian dalam bahasa Ibrani adalah "beresyit”, artinya "pada mulanya", yang diambil dari kata pertama kitab tersebut. Nama ini tepat, karena Kitab Kejadian menceritakan awal dari segala sesuatu yang berhubungan dengan iman umat Allah dalam Alkitab. Alkitab bahasa Yunani (Septuaginta) adalah "geneseos", artinya "permulaan", atau "generasigenerasi", yang diambil dari bahasa Ibrani "toledot", yang muncul sebelas kali dalam Kitab Kejadian, yang berfungsi sebagai petunjuk garis besar yang tepat. Alkitab bahasa Indonesia, memakai nama "Kejadian”.

\section{A. ANALISA HISTORIS KITAB KEJADIAN}

Setiap kitab di dalam Alkitab memiliki latar belakang historis masingmasing, sesuai konteks di mana, mengapa, dan untuk siapa kitab itu ditulis. Sehingga kita tidak menafsirkannya secara gegabah.

\section{Penulis dan Tahun Penulisan Kitab Kejadian}

\footnotetext{
6 -----------, Kamus Besar Bahasa Indonesia. Jakarta: Balai Pustaka, 1995, h. 352

${ }^{7}$ John Echol dan Hasan Shadily, Kamus Inggris-Indonesia. Jakarta: PT Gramedia, 1981, h. 738
} 
Jika berbicara tentang Kitab Kejadian, tidak bisa dilepaskan dari Pentateukh atau disebut juga Torah, yaitu lima kitab Musa, Kejadian sampai dengan Ulangan. Sastra alkitabiah memperlakukan Pentateukh sebagai satu kitab, yang secara tradisional diakui bahwa Musa-lah penulisnya. ${ }^{8}$ Namun ada bermacam-macam pendapat yang sangat jauh berbeda, yang berpandangan bahwa Pentateukh disusun dengan mengambil sumber-sumber, yaitu dari sumber J (Jahwist), sumber E (Elohim), sumber D (Deutoronomist), dan sumber P (Priest). Hasil temuan arkheologis dan kemajuan dalam penelitian kritis terhadap sastra Pentateukh sudah membuat perdebatan itu bertambah panas dalam abad ke-20 ini. ${ }^{9}$

Hingga tahun-tahun belakang ini, kebanyakan orang Yahudi sangat yakin bahwa Musa-lah penulis kitab-kitab Pentateukh. Pendapat ini didasarkan pada riwayat pengalaman Musa sendiri yang mendominasi kitab Pentateukh, sejak masa bayinya, masa kanak-kanaknya hingga dewasa di istana Firaun, masa pelariannya ke Midian, pemanggilan Tuhan atasnya, pengalaman membawa Israel keluar dari perbudakan Mesir, hingga bangsa Israel di tepi S. Yordan. Pengalaman Musa di istana Firaun, dengan pendidikan yang dia peroleh, memungkinkan dia memiliki kemampuan untuk menjadi seorang penulis yang baik. ${ }^{10}$ Tentang informasi yang disusun dalam kitab Kejadian, Musa mendapat bahan dari tradisi lisan (informasi yang diceritakan turun-tumurun), catatancatatan singkat mungkin dari prasastri-prasastri atau dari nisan, dan tentang penciptaan alam semesta, dinyatakan Allah langsung kepadanya. Bukti kepenulisan Musa a.1.: Tuhan menyuruh Musa untuk menulis suatu laporan tentang pertempuran melawan orang Amalek yang menyerang Israel (Kel. 17:14). Di G.Sinai, Musa menulis semua perkataan dan hukum yang difirmankan Tuhan (Kel. 24:4). Yosua disuruh Tuhan untuk merenungkan Taurat Musa (Yos. 1:7-8), dll.

Tahun penulisannya tentu selama Musa masih hidup. Bisa jadi selama dalam perjalanannya di padang gurun, Musa mencatat semua yang dia alami. Diperkirakan Musa lahir tahun 1500. Dan dia hidup selama 120 tahun.

${ }^{8}$ Andrew E. Hill \& John H. Walton, Survey Perjanjian Lama. Malang: Gandum Mas, 1996, h. 141

${ }^{9}$ Herbert Wolf, Pengenalan Pentateukh. Malang: Gandum Mas, 1991, h.63

${ }^{10}$ Ibid, h. 64-65 


\section{Alamat dan Tujuan Penulisan Kitab Kejadian}

Alamat Kitab Kejadian adalah bangsa Israel sendiri, sebagai umat pilihan yang dimulai dari pemanggilan Abraham, bapa leluhur mereka, yang dipanggil untuk menerima dan menjadi berkat (Kej.12:1-3). Berkat yang Tuhan berikan adalah keturunan seperti debu tanah, dan negeri Kanaan yang melimpah susu dan madunya (Kel.3:8).

Tujuan kitab Kejadian adalah menceritakan bagaimana dan mengapa Yahweh berkenan memilih keluarga Abraham dan mengadakan perjanjian dengan mereka. Perjanjian atau covenant ini merupakan dasar teologi dan identitas umat Israel. Karena itu dapat dipahami bahwa sejarah perjanjian itu penting. Dan selanjutnya dalam kitab ini dikisahkan tentang umat pilihan-Nya harus pergi ke Mesir, dengan demikian mempersiapkan suasana untuk peristiwa keluaran (exodus). ${ }^{11}$ Demikian pun Herbert Wolf berpendapat bahwa:

Kejadian ditulis sebagai suatu prolog untuk seluruh Alkitab, karena kitab ini mengisahkan asal-usul alam semesta, dunia fisik, kehidupan dan kebudayaan manusia, dan bangsa Israel. Banyak pertanyaan penting yang sudah berabad-abad lamanya membingungkan umat manusia, diuraikan dengan cekatan dan secara ringkas di pasalpasal pembukaan. Kita tidak hanya diberikan suatu laporan singkat dan agung mengenai penciptaan, tetapi kita juga diberitahu bagaimana dosa memasuki dunia dan bagaimana dosa itu merusak ciptaan yang semula dikerjakan oleh Allah. ${ }^{12}$

\section{Inti Berita Kitab Kejadian}

Kitab Kejadian mencatat sejarah karya Allah, yaitu karya penciptaan atas alam semesta, dan sejarah keselamatan bagi manusia ciptaan-Nya yang mulia yang telah jatuh dalam dosa. Kitab Kejadian juga membukakan tentang sifat

${ }^{11}$ Andrew E. Hill \& John H. Walton, Survey....., h. 147

${ }^{12}$ Herbert Wolf, Pengenalan ....., h. 104 
Allah yang baik, murah hati, tetapi juga kudus dan adil adanya. Allah telah menciptakan manusia sebagai makhluk mulia, tetapi juga harus menghukumnya karena dosa. Dan pada waktu yang sama, Allah juga menyediakan jalan keselamatan bagi manusia yang bersedia untuk bertobat.

\section{Analisa Konteks Kejadian 1-2}

Kitab Kejadian pasal 1-2 mencatat karya Allah yang menciptakan seluruh alam semesta, di mana penciptaan manusia sebagai puncaknya. Dan di pasal dua, menceritakan proses penciptaan manusia secara khusus, dan bagaimana relasi kedua gender, serta pembentukan lembaga pertama, yakni sebuah keluarga. Namun apa yang sangat indah, yang Tuhan telah ciptakan, telah menjadi rusak oleh karena ulah manusia yang tidak setia dalam memelihara perintah Allah, dan lebih cenderung memberi telinga kepada Iblis. Maka akibatnya, kutuk, baik untuk manusia pertama dan seluruh keturunannya, serta bagi seluruh alam.

\section{B. JATI DIRI PEREMPUAN MENURUT KEJADIAN 1-2}

Dua pasal pertama Kitab Kejadian membukakan citra (/jati diri) perempuan.

1. Perempuan, sama halnya laki-laki, diciptakan segambar/serupa Allah (Kej. 1:26). Dalam ayat 26 awal ditulis: "Dan Allah telah berfirman: "Marilah kita menjadikan manusia menurut gambar Kita seperti rupa Kita." Dalam teks Ibrani, kata gambar dan kata rupa sebenarnya sinonim. Kata Ibrani bestalmenu, kata dasarnya adalah stelem artinya image (gambar). Terjemahan lama LAI: peta. Dan frasa seperti rupa Kita dalam teks Ibrani kidmutenu dari kata dasar demut artinya likeness (kesamaan), atau similitude (keserupaan). ${ }^{13}$ Dalam Alkitab terjemahan LAI ada kata "dan" di antara kedua kata tersebut: menurut gambar dan rupa Kita". Terjemahan Jewish Bible ada koma di antaranya: in our emage, in the likeness of ourselves. Begitu juga terjemahan NIV: in our image, in our

\footnotetext{
${ }^{13}$ Francis Brown, The New Brown-Driver-Briggs-Gesenius Hebrew and English Lexicon. Peabody, Massachusetts: Hendrickson Publishers, 1979, p. 853 \& 198
} 
likeness. Terjemahan yang lebih tepat seharusnya tidak boleh disela dengan kata "dan" atau tanda koma, karena kata kedua (rupa) mempertegas kata pertama (gambar). Dengan kata lain, manusia diciptakan segambar atau serupa Allah, bukan "sama" dengan Allah. Kedua istilah ini, sebagai ungkapan figuratif tentang citra manusia, termasuk perempuan, yang memiliki relasi yang istimewa dengan Sang Pencipta, yang dikaruniai sebagian dari sifat-sifat Ilahi, dan sebagai mandataris Allah di bumi, yang diberi tugas dan otoritas sebagai manager seluruh alam semesta. ${ }^{14}$ W.S. Lasor, D.A.Hubbard \& F.W.Bush memberi komentar dengan istilah ini, demikian:

Sebenarnya, maksud penulis dalam mempergunakan konsep ini tampaknya jauh lebih bersifat fungsional daripada konseptual. Ia lebih menaruh minat pada akibat-akibat pemberian itu daripada sifatnya. Keserupaan itu bersifat dinamis, yakni manusia (adam) dalam hubungan pribadinya dengan makhluk-makhluk lain menjadi wakil Allah. Ia diberi hak untuk menyelidiki, menguasai dan mempergunakan segala sesuatu di sekitarnya. ${ }^{15}$

Dari teks ini jelas bahwa tidak ada diskriminasi antara laki-laki dan perempuan. Keduanya memiliki kedudukan yang sama di hadapan Tuhan. Juga Tuhan memberi kepercayaan, tugas dan otoritas yang sama atas alam semesta.

2. Perempuan adalah penolong sepadan bagi laki-laki/suaminya (Kej.2:18). Jewish Bible menterjemahkan a companion suitable. NIV menterjemahkan a helper suitable. Kata penolong dalam bahasa Ibrani ezer dari kata kerja dasarnya azar artinya menolong atau mendukung. Dari arti kata ini mengindikasikan bahwa sebenarnya memiliki kelebihan tersendiri dari pada laki-laki, sehingga dia bisa menjadi penolong atau pendukung laki-laki/suaminya. Dalam kenyataan memang, dalam hal-hal tertentu, perempuan lebih kuat dari pada laki-laki/suaminya, atau sebaliknya laki-laki lebih lemah sehingga membutuhkan pertolongan atau dukungan perempuan/isterinya. Dalam hal mental, perempuan lebih tabah, misalnya

14 John F. Walvoord \& Roy B. Zuck, The Bible Knowledge Commentary. Wheaton Illinois: Victor Books, 1985, p. 29

${ }^{15}$ W.S. LaSor \& D.A. Hubbard \& F.W. Bush, Pengantar Perjanjian Lama I. Malang: Gandum Mas, 2001, h. 123 
para janda lebih mampu bertahan memelihara anak-anak sampai akhir, dibanding para duda yang cenderung mencari pengganti isterinya yang sudah tiada. Secara fisik perempuan lebih kuat, terbukti mampu mengandung dan melahirkan serta menyusui anaknya, serta mengerjakan banyak pekerjaan praktis dalam rumah tangganya. Secara rohani, perempuan lebih responsive dan lebih tekun dari pada laki-laki. Dalam hal integritas, perempuan lebih setia dari pada laki-laki.

Istilah sepadan dalam bahasa Ibrani neged, artinya apa yang di depan mata, atau cocok/sesuai. ${ }^{16}$ Dari arti kedua kata di atas, jelas posisi dan peran perempuan di hadapan laki-laki adalah sebagai penolong atau pendukung laki-laki/suaminya, bukan pemimpin yang mendominasi, dan bukan juga sebagai budak yang boleh diperlakukan semena-mena, sebagai obyek pemuas nafsu, atau sebagai manusia kelas dua. Dalam melaksanakan mandat budaya (beranak cucu dan memelihara alam), laki-laki membutuhkan perempuan, karena tidak mungkin melaksanakannya dengan binatang. Meskipun Tuhan sudah membawa semua binatang kepada Adam untuk diberi nama, namun Adam tetap kesepian (merasa sendirian), karena binatang bukan penolong sepadan untuk Adam. David Atkinson memahami istilah penolong sepadan demikian:

Kata sifat kenegdo agaknya bertalian dengan kata kerja yang berarti "menjadi jelas atau kentara". Kata benda yang bertalian menunjuk kepada seorang yang ulung. Jadi dengan "seorang penolong yang sepadan", mungkin yang dimaksud ialah penolong yang sama ulungnya, atau sama kekhususannya. Ini menunjukkan bahwa penolong ini pasti layak berdiri di hadapan manusia sebagai imbangannya, temannya, pelengkapnya. Tidak terkandung di sini rasa inferioritas, rasa di bawah ukuran atau rasa diperuntukkan sebagai budak, melainkan seorang yang mirip dengan dia tapi "kebalikan dari dia". 17

${ }^{16}$ Francis Brown, The New Brown-Driver ....., p. 617

${ }^{17}$ David Atkinson, Kejadian 1-11. Jakarta: Yayasan Komunikasi Bina Kasih, 1996, h. 83 


\section{Tubuh perempuan dibentuk dari salah satu tulang rusuk laki-laki} (Kej. 2:21-22). Praktek pembedahan pada tubuh manusia, pertama kali dilakukan oleh Allah sendiri, untuk mengambil salah satu dari tulangtulang rusuknya, dan kemudian Tuhan menutupnya dengan daging. Tidak perlu dipertanyakan mengapa Tuhan mengambil tulang rusuk untuk membentuk seorang perempuan. Mengapa bukan tulang kepala atau tulang tangan, atau tulang kaki? Kenyataan ini memberi penekanan tentang keterikatan yang kuat antara laki-laki dan perempuan. Atau dengan kata lain, perempuan adalah bagian dari laki-laki. Laki-laki yang lebih dulu dibentuk, baru kemudian dari laki-laki dibentuk seorang perempuan. Dari sini bisa muncul adanya hirarkhi, di mana laki-laki sebagai pemimpin keluarga, namun pemimpin yang mengatur dengan bijak dan mengayomi, karena perempuan adalah bagian dari dirinya. Matthew Henry menulis dalam commentarynya demikian: That the woman was made of a rib out of the side of Adam; not made out of his head to rule over him, nor out of his feet to be trampled upon by him, but out of his side to be equel with him, under his arm to be protected, and near his heart to be beloved. ${ }^{18}$ Jadi menurut Matthew Henry, perempuan dibentuk dari tulang rusuk laki-laki, untuk dilindungi dan dikasihi. Perempuan adalah mitra dalam melaksanakan mandat kebudayaan: beranak-cucu dan mengelola alam semesta ini.

\section{GERAKAN FEMINISME DI INDONESIA}

Dalam buku Ensiklopedia Feminisme, feminisme adalah penggabungan doktrin persamaan hak bagi perempuan (gerakan terorganisir untuk mencapai hak asasi perempuan) dan sebuah ideology transformasi sosial yang bertujuan untuk menciptakan dunia bagi perempuan melampaui persamaan sosial yang sederhana. Secara umum, feminisme adalah ideology pembebasan perempuan karena yang melekat dalam semua pendekatannya adalah keyakinan bahwa perempuan mengalami ketidakadilan karena jenis kelaminnya. ${ }^{19}$ Singkatnya,

\footnotetext{
${ }^{18}$ Matthew Henry, Matthew Henry's Commentary on the Whole Bible. McLean, vol. 1. Virginia: MacDonald Publishing Company, 1706, p.20

${ }^{19}$ Maggie Hunim, Ensiklopedia Feminisme. Panguntapan: Fajar Pustaka Baru, 2002, h. 158
} 
Missio Ecclesiae, 2(2), Oktober 2013, 125-142

Feminisme adalah sebuah gerakan perempuan yang menuntut emansipasi atau kesamaan dan keadilan hak dengan laki-laki.

\section{A. SEJARAH GERAKAN FEMINISME}

Gelombang pertama: Feminisme sebagai filsafat dan gerakan dapat dilacak dalam sejarah kelahirannya dengan lahirnya era Pencerahan di Eropa yang dipelopori oleh Lady Mary Wortley Montagu dan Marquis de Condorcet. Perkumpulan masyarakat ilmiah untuk perempuan pertama kali didirikan di Middelburg, selatan Belanda, tahun 1785. Menjelang abad-19 Feminisme menjadi gerakan yang cukup mendapat perhatian dari para perempuan kulit putih di Eropa. Pada awalnya gerakan ini memang diperlukan pada masa itu, di mana ada masa-masa pemasungan terhadap kebebasan perempuan. Sejarah dunia menunjukkan bahwa secara umum kaum perempuan merasa dirugikan dalam semua bidang dan dinomor-duakan oleh kaum laki-laki, khususnya dalam masyarakat yang patriarkat, baik di bidang sosial, pekerjaan, pendidikan, dan politik. Apalagi masyarakat tradisional yang berorientasi agraris cenderung menempatkan kaum laki-laki di depan, di luar rumah, sedangkan kaum perempuan di rumah saja. ${ }^{20}$

Gelombang kedua: setelah berakhirnya perang dunia II, ditandai dengan lahirnya negara-negara baru yang terbebas dari penjajahan Eropa, maka lahirlah Feminisme gelombang kedua, tahun 1960. Pada tahun ini merupakan awal bagi perempuan mendapatkan hak pilih, dan selanjutnya ikut mendiami ranah politik kenegaraan. Pelopor gerakan Feminisme gelombang kedua ini adalah Helene Cixous di Perancis (seorang Yahudi kelahiran Aljazair yang kemudian menetap di Perancis), dan Julia Kristeva (seorang Bulgaria, yang kemudian menetap di Perancis). Secara lebih spesifik, banyak feminisindividualis kulit putih, meskipun tidak semua, mengarahkan obyek penelitiannya pada perempuan-perempuan dunia ketiga, meliputi: Afrika, Asia, dan Amerika Selatan. Sebelumnya banyak pejuang tanah terjajah Eropa yang lebih mementingkan kemerdenaan bagi laki-laki saja. Dengan keberhasilan gelombang kedua ini, perempuan dunia pertama melihat bahwa mereka perlu

${ }^{20}$ Wapedia - Wiki: Feminisme, http://wapedia.mobi/id/Feminisme, diakses 29

Desember 2009, h.1-2 
menyelamatkan perempuan-perempuan dunia ketiga, dengan asumsi bahwa semua perempuan adalah sama. ${ }^{21}$

Gelombang ketiga: di Amerika Serikat, gerakan Feminisme lebih keras bergaung pada era perubahan dengan terbitnya buku The Feminine Mystique yang ditulis oleh Betty Friedan, tahun 1963. Friedan membentuk organisasi wanita bernama National Organization for Woman, tahun 1966, yang gemanya merambat ke segala bidang kehidupan. Gerakan Feminisme berjalan terus, sekalipun sudah ada perbaikan-perbaikan, kemajuan yang dicapai gerakan ini terlihat banyak mengalami halangan. ${ }^{22}$

Pandangan yang merendahkan perempuan bukan hanya ada di luar kekristenan. Di dalam gereja sendiri, tradisinya, seringkali perempuan dipandang sebagai harta milik, obyek, polusi yang membahayakan, dan yang paling keras adalah, perempuan dinilai tidak mampu menjadi gambar Allah, sehingga mereka dilarang menjadi pemimpin, pengkhotbah, dan pengajar dalam ibadah maupun pelayanan di gereja. ${ }^{23}$ Karena itu lahirlah theology feminisme, yang memperjuangkan pembebasan dari patriarkhat dan menuju hubungan baru. Artinya pihak yang tadi berkuasa, melepaskan tuntutan dan kesombongannya, lalu membuka diri pada pihak yang lemah. Theologi Feminis di Asia, Afrika, dan Amerika Latin lahir dari pengalaman rohani dan tanggung jawab mereka yang merenungkan realitas Allah dan dunia. Theologi ini lahir dari kesengsaraan dan penghinaan kaum perempuan, dan keinginan memperoleh martabat dan keutuhan hidup. ${ }^{24}$

\section{B. PENGARUH GERAKAN FEMINISME DALAM GEREJA DI INDONESIA}

Kaum perempuan di Indonesia mengalami "nasib" yang serupa dengan para perempuan di negara-negara berkembang lainnya. Perempuan dianggap manusia kelas dua, orang belakang saja, tidak pantas tambil di forum, apalagi berbicara di khalayak ramai, menduduki posisi kepemimpinan, ataupun

\footnotetext{
${ }^{21}$ Ibid, h.4-6

${ }^{22}$ Wapedia - Wiki: Feminisme, ....., h. 6-8

${ }^{23}$ Lie Ing Sian, Sebuah Tinjauan terhadap Teologi Feminis Kristen. www.seabs.ac.id. Diakses 29 Desember 2009, h.3

${ }^{24}$ Marie Claire Barth Frommel, Pengantar Teologi ...... h.14,21
} 
mendapat hak pendidikan yang layak, dan tidak memiliki hak bersuara. Perempuan juga dianggap sebagai obyek pemuas nafsu, pelampiasan emosi laki-laki, bertugas melahirkan banyak anak dan merawat anak-anaknya, dikomersiilkan (misalnya di iklan-iklan, sebagai pajangan di toko/mall, dll.), menjadi tontotan umum. Karena itu pulalah kaum perempuan di Indonesia menyambut gerakan Feminisme yang bangkit, baik di Eropa, Afrika, dan di Amerika Latin.

Lain halnya dengan pelopor yang memperjuangkan nasib kaum perempuan adalah R.A. Kartini, yang kemudian diperingati perjuangannya tiap tgl. 21 April, karena dia telah memperjuangkan agar kaum perempuan mendapat kesempatan mengembangkan diri melalui bidang pendidikan. Itulah masa pencerahan bagi kaum perempuan Indonesia. Namun praktek di lapangan, diskriminasi terhadap kaum perempuan, baik secara terbuka maupun secara terselubung sulit untuk diberantas, karena hal itu sudah menjadi tradisi turun-tumurun. ${ }^{25}$

Di dalam Gereja sendiri, tidak lepas dari budaya bangsa Indonesia. Memang sudah banyak kemajuan, terbukti banyak kaum perempuan studi theologia secara formal, dan mendapat gelar, bahkan sampai ke jenjang S.3. Banyak pula perempuan yang menjadi pemimpin gereja ataupun lembaga gerejawi. Namun ada beberapa denominasi gereja yang masih memegang doktrin bahwa perempuan tidak boleh berbicara di depan forum dan/atau berkhotbah/mengajar. Kalaupun seorang perempuan selesaikan studi theologia, hanya sebatas menjadi majelis jemaat, melayani anak-anak, atau melayani ibuibu, anak-anak, dsb.

\section{SIKAP KRISTIANI TERHADAP GERAKAN FEMINISME DI INDONESIA}

Sikap Kristiani yang penulis maksudkan adalah bagaimana sikap orang Kristen terhadap Gerakan Feminisme. Di bawah ini penulis menjelaskan sikap Kristiani terhadap Gerakan Feminisme.

\footnotetext{
25 http://leeanarea_blogspot.com.id, diakses 29-12-2009, h. 5
} 
Sebenarnya orang Kristen menghargai perempuan dan hak-haknya bukan karena adanya gerakan Feminisme muncul. Tetapi baik juga, bahwa gerakan Feminisme membantu orang Kristen untuk kembali mengingat ketetapan Allah tentang jati diri perempuan. Hanya saja jangan sampai mengikuti arus Gerakan Feminisme yang bermuatan negative, dengan melakukan gerakan-gerakan yang fulgar, misalnya melakukan demonstrasi massal menuntut hak-haknya, atau mengadakan gerakan-gerakan yang mau mendominasi kaum laki-laki, dan melepaskan tanggung jawabnya sebagai isteri dan ibu bagi anak-anaknya, serta tugas-tugas lain sebagai wanita. Juga Feminisme yang mempengaruhi dunia Theologia, di mana kaum perempuan melahirkan pola penafsiran Alkitab dari sudut pandang perempuan, dan demi kepentingan perempuan, sehingga jatuh pada ekstrim yang bersifat menyesatkan.

Yang dapat mengubah konsep manusia tentang penilaian dan sikap terhadap kaum perempuan adalah jika benar-benar memahami jati diri perempuan menurut Firman Tuhan, terkhusus dibukakan dalam Kejadian 1-2.

Kitab Kejadian 1-2 membukakan kebenaran tentang jati diri perempuan. Itu harus difahami oleh setiap orang Kristen, baik laki-laki maupun perempuan. Sejak penciptaan, laki-laki dan perempuan diciptakan sederajat di hadapan Allah, tidak ada perbedaan kedudukan atau diskriminasi. Keduanya juga diberi tugas yang sama untuk melaksanakan amanat budaya, baik beranak cucu maupun untuk mengelola alam semesta ini. Meskipun perannya mungkin beda dalam hal-hal tertentu, namun nilainya sama di hadapan Tuhan. Karena itu sikap Kristiani terhadap perempuan juga adalah: menempatkan perempuan secara proposional, memberi hak suara, hak untuk mengembangkan diri, hak untuk beraktualisasi diri, hak untuk mengungkapkan sebagai orang rendah, orang rumah saja, pemuas nafsu, obyek komersiil, dsb.

Seyogyanya orang Kristen memberi penghormatan kepada perempuan, sebagaimana kepada laki-laki, meskipun tugasnya ada perbedaan dalam hal-hal tertentu. Sementara itu, kaum perempuan Kristen juga harus menghargai dirinya sendiri secara wajar, tidak rendah diri, dan juga sebaliknya tidak overacting. 


\section{KESIMPULAN DAN SARAN}

Gerakan Feminisme lahir dari kerinduan para perempuan ingin keluar dari kungkungan atau tekanan budaya patriarkhat yang cenderung merendahkan dan merugikan kaum perempuan. Dan gerakan Feminisme ini juga berpengaruh dalam Theologia, sehingga melahirkan Theologia Feminisme, yang melahirkan juga pola-pola penafsiran Alkitab, yang menguntungkan kaum perempuan. Gerakan Feminisme di Indonesia bisa memotivasi kaum perempuan untuk mendapatkan hak-haknya. Namun gerakan ini tidak mampu secara tuntas meniadakan budaya patriarkhat yang sudah mendarah-daging di masyarakat Indonesia. Untuk itu, kaum perempuan, terma suk perempuan Kristen tidak bisa memaksakan haknya. Di kalangan Gereja, tentunya bukan karena adanya Gerakan Feminisme barulah orang Kristen memberi penghargaan kepada kaum perempuan secara proporsional, melainkan berdasarkan Firman Tuhan sendiri, khususnya dalam Kitab Kejadian pasal 1-2, di mana perempuan diciptakan Tuhan sejajar dengan lakilaki, yakni menurut gambar atau rupa Allah sendiri, dengan tugas yang sama dalam melaksanakan Amanat Budaya, meskipun peran konkritnya berbeda. Dalam relasinya dengan laki-laki/suami, perempuan bertugas sebagai penolong/ pendukung. Ini satu tugas yang istimewa. Dan bahwa perempuan diciptakan untuk dikasihi dan dilindungi, karena dari satu tulang rusuk yang berasal dari laki-laki.

Adapun beberapa saran konkrit bagi semua pembaca pembahasan topik ini adalah sebagai berikut:

1) Orang Kristen penting untuk memiliki pemahaman yang benar tentang jati diri perempuan menurut Kitab Kejadian 1-2, bahwa laki-laki dan perempuan diciptakan sederajat sebagai gambar atau rupa Allah sendiri, dengan mandat yang sama, meskipun fungsinya ada yang berbeda. Perempuan ditetapkan Allah sebagai penolong bagi laki-laki/suami, bukan pemimpin yang mendominasi laki-laki, dan bukan pula budak yang bisa diperlakukan sekehendak laki-laki. Perempuan diciptakan Tuhan dari tulang rusuk laki-laki, untuk dikasihi dan dilindungi. Dengan memahami kebenaran Firman Tuhan ini, maka orang Kristen tidak perlu terpancang kepada gerakan Feminisme yang baru lahir pada abad 19. 
2) Orang Kristen perlu mengenal gerakan Feminisme dan pengaruhnya di Indonesia. Meskipun orang Kristen sudah memiliki pemahaman Firman Tuhan tentang keberadaan dan status perempuan, namun perlu juga mengenal gerakan Feminisme dan pengaruhnya di Indonesia, supaya bersikap antisipatif terhadap ekses-ekses negative dari gerakan ini, misalnya demonstrasi menuntut hak perempuan, ataupun melakukan berbagai aksi yang fulgar dan overacting.

3) Sistem hermeneutik gerakan Feminisme bersifat bebas, yang penting menguntungkan kaum perempuan. Maka system hermeneutik seperti ini sangat menyesatkan, karena memaksakan Firman Allah untuk memenuhi kebutuhan atau kepentingan si penafsir. Karena itu orang Kristen jangan mengadopsi sistem hermeneutik gerakan Feminisme.

4) Gereja kiranya sangat mewaspadai pengaruh gerakan ini yang bisa menyusup secara halus di dalam jemaat, dengan kedog rohani, khususnya di kalangan kaum perempuan, misalnya kaum perempuan mengadakan banyak kegiatan rohani di luar rumah, membuat organisasi tertentu dengan sering mengadakan meeting, yang pada akhirnya melalaikan tugas pentingnya di dalam keluarga, bahkan sudah tidak lagi menghargai suaminya sebagai kepala keluarga.

5) Di sisi lain, Gereja seyogyanya memposisikan kaum perempuan secara proporsional, sesuai Firman Allah, dan sesuai talenta dan kemampuan yang dimiliki oleh tiap perempuan di dalam jemaatnya. Jangan pernah meremehkan kaum perempuan, karena Tuhan sudah meletakkan potensipotensi khusus di dalam diri perempuan, yang kaum laki-laki tidak memilikinya, sehingga akan lengkap jika kaum perempuan dan kaum lakilaki bekerja bersama-sama.

\section{DAFTAR PUSTAKA}

Atkinson, David

1996 Kejadian 1-11. Jakarta: Yayasan Komunikasi Bina Kasih

Barth, Marie Claire Barth-Frommel

2003 Hati Allah Bagaikan Hati Seorang Ibu. Pengantar Teologi Feminis. Jakarta: BPK Gunung Mulia 
Missio Ecclesiae, 2(2), Oktober 2013, 125-142

Brown, Francis

1979 The New Brown-Driver-Briggs-Gesenius Hebrew and English

Lexicon. Peabody, Massachusetts: Hendrickson Publishers

1995 Kamus Besar Bahasa Indonesia. Jakarta: Balai Pustaka

Henry, Matthew

1706 Matthew Henry's Commentary on the Whole Bible. McLean, vol. 1. Virginia: MacDonald Publishing Company

Hill , Andrew E. \& John H. Walton 1996 Survey Perjanjian Lama. Malang: Gandum Mas Hunim, Maggie

2002 Ensiklopedia Feminisme. Panguntapan: Fajar Pustaka Baru

John, Echol dan Hasan Shadily

1981 Kamus Inggris-Indonesia. Jakarta: PT Gramedia

LaSor, W.S. \& D.A. Hubbard \& F.W. Bush,

2001 Pengantar Perjanjian Lama I. Malang: Gandum Mas

Wolf, Herbert

1991 Pengenalan Pentateukh. Malang: Gandum Mas

Walvoord, John F., \& Roy B. Zuck

1985 The Bible Knowledge Commentary. Wheaton Illinois: Victor Books

\section{Diakses dari Internet:}

Aloys Budi Purnomo, dalam artikel "Agama \& Kekerasan Terhadap Perempuan”. http//www.kesrepo.info/?q=rode/186. Diakses tgl. 21-12-2009

http://leeanarea_blogspot.com.id, diakses 29-12-2009

Wapedia - Wiki: Feminisme, http://wapedia.mobi/id/Feminisme, diakses 29

Desember 2009

Lie Ing Sian, Sebuah Tinjauan terhadap Teologi Feminis Kristen.

www.seabs.ac.id. Diakses 29-12-2009 